\title{
The Study of Government's Role for Welfaring Rubber Farmer in The Globalization Vortex
}

\author{
Pahrudin HM•
}

\begin{abstract}
Rubber is a type of plant that has been cultivated by the people of Indonesia for long a time. Until now, farmers have become the largest party to cultivate rubber in Indonesia $(85.10 \%)$ and contribute greatly to the nation's economy, but are still far from prosperous. Rubber products produced by farmers are priced cheap so that they incomes are very small and create income inequality. As an export commodity, rubber is highly dependent with overseas which determines the price. In this context, the government through the bureaucratic system serves to produce a series of innovative-solutive development program in order to keep the people from the negative impacts of globalization. This effort can be run by the government with adopting The New Public Service Paradigm as part of efforts to better public services for the people. It is implementation in the form of domestic rubber needs priorities, bringing the industry to the center of rubber, training of rubber farmers, and improvement of transportation infrastructures.
\end{abstract}

\section{Keywords:}

rubber farmer; globalization; state role; New Public Service.

\section{Introduction}

The study of the existence of rubber becomes interesting topic because its contribution to the Indonesian economy is quite significant. Based on data from the Central Bureau of Statistics (BPS) (2014), 2,623,425 million tons $(83.20 \%)$ of total rubber production (3.153.186 million tonnes) is destined for exports and generated US $\$ 4,741,489$ million used to finance development projects in Indonesia. However, what is obtained by the main manager, rubber farmers, is not directly proportional to the contribution it provides. This is because rubber farmers are still facing a series of problems in the cultivation of this type of plant that has an impact on their life.
Historically, rubber is a type of plant that has been cultivated by the Indonesians since a long time, i.e., in the time range of 19101911. Starting from an interest in the success and profit of Dutch plantation companies, although still a sideline business from the main activities as a food crop farmer, such as rice and vegetables (Padmo, 2004: 110).

Nationally, Indonesia has a total of $3,555,946$ hectares of rubber plantations spread throughout the country, mainly on the island of Sumatra and Kalimantan (BPS, 2014). A total of $3,026,020 \mathrm{Ha}$. $(85.10 \%)$ of the total national rubber are owned by the people/farmers, thus certainly contributing greatly to the nation's economy as much as $2,623,425$ million tons $(83.20 \%)$ of total rubber production $(3,153,186$

\footnotetext{
- Department of Political Science, Faculty of Social and Political Sciences, Jambi University.

Email: pahrudinhm9@gmail.com
} 
Million tons) is earmarked for export and produces US $\$ 4,741,489$ million. Rubber is also a type of plant that has long been cultivated by people in Jambi Province.

Table 1.

Area of Rubber Plant in Indonesia (Ha.)

\begin{tabular}{cccccc}
\hline Year & PR & PBN & PBS & Amount & $\begin{array}{c}\text { Growth } \\
(\%)\end{array}$ \\
\hline 2013 & $3,026,020$ & 247,068 & 282,858 & $3,555,946$ & 1.42 \\
2014 & $3,062,931$ & 249,040 & 294,274 & $3,606,245$ & 1.41 \\
2015 & $3,098,861$ & 251,033 & 306,163 & $3,656,057$ & 1.38 \\
\hline
\end{tabular}

Source: Statistics Indonesia Rubber BPS, 2014.

Note. :

$P R \quad:$ Smallholder

PBN : National Large Estates (PTPN)

PBS : Big Private Plantation.

Table 2.

The Volume of Indonesian Rubber Export, 2012-2014

\begin{tabular}{ccccc}
\hline \multirow{2}{*}{ Year } & \multicolumn{2}{c}{ Natural Rubber } & \multicolumn{2}{c}{ Growth } \\
\cline { 2 - 5 } & $\begin{array}{c}\text { Volume } \\
\text { (Ton) }\end{array}$ & $\begin{array}{c}\text { Value } \\
(\text { 000 US\$) }\end{array}$ & $\begin{array}{c}\text { Volume } \\
(\%)\end{array}$ & $\begin{array}{c}\text { Value } \\
(\%)\end{array}$ \\
\hline 2012 & $2,444,438$ & $7,861,378$ & -4.35 & -33.16 \\
2013 & $2,701,995$ & $6,906,952$ & -10.54 & -12.14 \\
2014 & $2,623,425$ & $4,741,489$ & -2.91 & -31.35 \\
\hline
\end{tabular}

Source: Statistics Indonesia Rubber BPS, 2014.

The amount of rubber contribution was not directly proportional to the condition of rubber farmers as the main manager of national rubber production. Until now, rubber farmers still face problems related to product quality and low productivity, technology and simple marketing system.

The problem faced by rubber farmers is the lack of government attention to rubber farmers in the cultivation of this plant. Although the government has given birth to various policies, one of them is the Nucleus Estate (PIR), but still has not been able to overcome the problems faced by farmers. According to Padmo (2004: 117), even though the PIR has been applied by the government, farmers still have problems with the inability to pay off their credit, the sale of rubber materials out of the core, low quality and variety of bokar and excessive rubber plantation exploitation. The official Plantation Revitalization Program also fared the same. Implementation of this program runs slowly, and this goal is difficult to achieve due to inhibiting factors that cannot be overcome (Rulyantie, 2011). The Rubber Rejuvenation Program issued by the Jambi Provincial Government in 2006 has not been able to solve the problems faced by rubber farmers. This is because the policy does not address the real problems facing rubber farmers, namely: price issues.

The problems faced above have an impact on the farming economy (Napitupulu, 2011; Sunarti, 2011; HM, 2014). As the main livelihoods, farmers rely heavily on the results obtained from rubber concessions. When the results get better, the farmers economy and their family will be better, but when the sales results are not satisfactory, the farmers life also slumps. The economic downturn experienced by farmers due to the unfavorable results of rubber gains has had an impact on the welfare of their lives. As a result, many of the necessities of life, both clothing, shelves and food, that farmers cannot fulfill, so that their lives farther away from prosperity.

Various problems faced by rubber farmers above certainly does not appear without any cause. Especially faced with the fact that farmers become the main manager of rubber in the country $(85.10 \%)$ and produce division US\$ 4,741,489 million for the country. As one of Third World's important resources due to its significant role in the economy, rubber is of course inextricably linked to the impact of the global economic system, primarily because of its status as an export commodity. Thus, the existence of farmers as the main actors of rubber management is strongly influenced by the existing policies at the global level. Based on the perspective of the skeptical theory of globalization, the problem faced by rubber farmers of Tabir Ilir is the local impact of capital penetration applied in the Third World. This 
is because what happens in the local realm is an implication of the workings of the global capital system. Thus, exploring the problems facing rubber farmers is a consequent impact of capital penetration that controls natural resources in the Third World through the role of its agents in the era of globalization. According to the skeptical theorists (Petras and Veltmeyer, 2011, Gilpin and Gilpin, 2000, Amin, 2001), the backwardness and powerlessness of the people in the Third World is the impact of globalization which is nothing but a new manifestation of imperialism.

Studies show the absence of government policies that pro people make people's lives in powerlessness and poverty amid the penetration of global capitalism. This is as shown in Mitrović (2010) study about the conditions of post-socialist societies under the influence of neoliberal development strategies and restoration of peripheral capitalism. Through uncritical acceptance of the modernization strategy of neoliberal dependence receive from the West, the compradore bourgeoisie and political elite has contributed more to the process of destruction than creation. This group brings a peripheral economic system in Serbian society to the point that this country and the Balkans generally enter into the circle of peripheral capitalism. Although their place is separate from each other, they do the same activity, which is exploiting the community.

The study of Jati (2012) also highlights the economic imbalances in globalization. Such inequality is particularly manifest in the phenomenon of poverty, income inequality, and increased debt for Third World countries. This implication indicates an unequal process of globalization between an increasingly wealthy Forward Country and a poorer Third World country. In another study, Jati (2013) said that colonialism in the era of globalization itself is manifested in the control of large capital that moves between nations and countries. Under these circumstances, the Forward
Countries benefit from having a comparative advantage of technology and banking, while Third World countries rely only on extractive resource results. However, the exchange of resources between the two actors is not in an equal position. The Forward States themselves benefit from international trade regulations that allow them to have a veto in the flow of trade. The condition is in contrast to the Third World countries who are in a position to accept and have no Minimized State votes.

Still, in the same context, Napitupulu (2011) states that smallholder rubber farmers are identical with poverty for failing to improve their standard of living in Jambi. Rubber farmers live in conditions that are far from decent living standards, due to poor earnings due to the result that its rubber business is not qualified and priced lower in the market. Same condition as shown in Sunarti's (2011) study also stated that rubber is one of the main export commodities in Jambi Province whose demand is increasing. Amid the high volume of exports, Jambi rubber farmers face various problems. Rubber farming in is generally a conventional or traditional smallholder rubber farming business because farmers have limited capital. The income of farmers from rubber farming business ranges from IDR 320.000 - IDR 480,000 per month; the income is still below Minimum Wage Standard (UMR) Bungo District (IDR. $716,000 /$ month), although the area of land holding in this area is $3.82 \mathrm{Ha}$./family.

On the basis of it, this paper is intended to analyze the existence of rubber farmers in the context of globalization and propose innovative solutions in an effort to overcome the problems faced by the main actors of rubber management so that life becomes better. Tabir Ilir District Merangin Regency Jambi Province was chosen as the location for this study because it is one of the main areas of rubber producers in Jambi Province (HM, 2014). According to data from the Merangin District Plantation and Forestry Office (2015), the rubber area in Tabir Ilir 
District is the largest in Merangin Regency, which is 15,787 hectares $(12.01 \%)$ and is a smallholder rubber $(8,050$ farmers $)$. As with BPS (2014) data, Jambi Province has the third largest rubber plantation area in Indonesia (662,213 hectares), mostly of smallholder rubber. Merangin Regency is the region with the largest rubber plantation area in Jambi Province, which is 130.948 Ha. (19.77\%), or $131,413 \mathrm{Ha}$. according to the Merangin Regency Plantation and Forestry Office.

\section{Methods}

This article used a qualitative research method that provide opportunities for researchers to be able to do a detailed description and interpretation in order to gain a holistic understanding (Marvasti, 2004: 7). The type of this research is case study that an approach to study, explain, or interpret a case in the context naturally without any intervention from outside (Denzin and Lincoln, 2009: 300-301). Rubber farmers of Tabir Ilir, rubber businessmen, and Local Government of Jambi Province and Merangin Regency are subjects of this study. Data were collected through documents and archive footage, interviews, direct observation, participant observation and other physical devices (Yin, 2004: 103-118). Data analysis used reducing data, displaying data, and drawing conclusion (Miles and Huberman, 1992: 15-21).

\section{Results and Discussion Globalization Discourse}

In general, globalization is understood by Ritzer (2006: 96) as a process of spreading global habits, the expansion of relationships across continents, the organization of social life on a global scale, and the growth of a common global consciousness. Meanwhile, according to Giddens (1990: 64), globalization is the intensification of world relationships that link the far-flung locality in such a way that a number of social events are shaped by events that occur over miles and vice versa. Thus it can be said that globalization is the integration of all aspects of human life, ranging from economic, information, political systems to cultural aspects.

Globalization has been massively enforced worldwide since 1980 and raises impact on the world community. On the one hand, globalization has a positive impact on the effort to obtain a decent standard of living (Friedman, 2007; Bryan and Farrell, 1996). This is because globalization provides the same competitive arena for each country to take advantage of the opportunities provided (Wolf, 2005).

On the contrary, globalization has also generated negative excesses around the world. According to Petras and Veltmeyer (2001), globalization is only enjoyed by the Developed Countries, while the Third World countries only serve as spectators, even the victims of the various negative excesses it causes. Globalization also marginalizes farmers in Third World countries because global trade rules make them increasingly marginalized, even uprooted from the systems, professions, and way of life that has been done (Shiva, 2003).

According to Amin (2001), globalization is a metamorphosis of the third Western occupation of the Third World, having previously practiced mercantilism and imperialism. Chakrabarty (2000) says that globalization is nothing but a manifestation of the European ambitions of rebuilding its hegemony using a series of historical imperialist practices in Third World countries. In the same context, Murshed (2002) and Steger (2010) also state that globalization is an attempt by the West, especially the British, in order to spread modernity and capitalism throughout the world.

Globalization also raises the debate among experts about the role of the state or government in development. The integration of the world politically, economically, culturally 
and information makes it easy for people to interact and take advantage of opportunities without being constrained by state status anywhere and anytime. As a result, the state's tertiary physical boundaries merge so that the government is considered to have little role in development (Winarno, 2005: 37).

The role issue played by the state has become one of the central themes in the debate surrounding globalization (Winarno, 2005). This is because as the party who handed over the responsibility of state management, the government as the manifestation of the state should play an active role in overcoming the problems faced by the people. Globalization with all its impacts needs to get the attention of the government so that its positive excesses can be put to good use and the negative excesses can be avoided by the people.

The debate over the role that the state or government play in this development according to Giddens (2002: 7-8) led to two major groups, namely Radical groups on the one hand and Skeptical groups on the other. Generally, Radical groups are identified as a collection of social thinkers who support globalization because they regard it as a necessity and useful in human life, while Skeptics are known as intellectuals who doubt the possibility, even against its existence because of the various negative excesses it causes.

\section{Tabir Ilir's Rubber Farmers in The Globalization Vortex}

On the basis of a skeptical thesis that poses it as a new form of colonization, globalization carries out its mission through its agents of various actors spread across multiple levels, ranging from global to local levels. Actors performing global mastering missions are played by rubber importing countries, while national actors are state/government and companies owning rubber processing factories, while locally-linked rubber-related agents are played by local entrepreneurs, as illustrated in the diagram below.

As mentioned earlier that rubber has always had a significant role in human life and has a major impact on the economy. This is understandable because the processed rubber

\section{Diagram 1.}

Tabir Ilir's Rubber Farmer in the Globalization Vortex

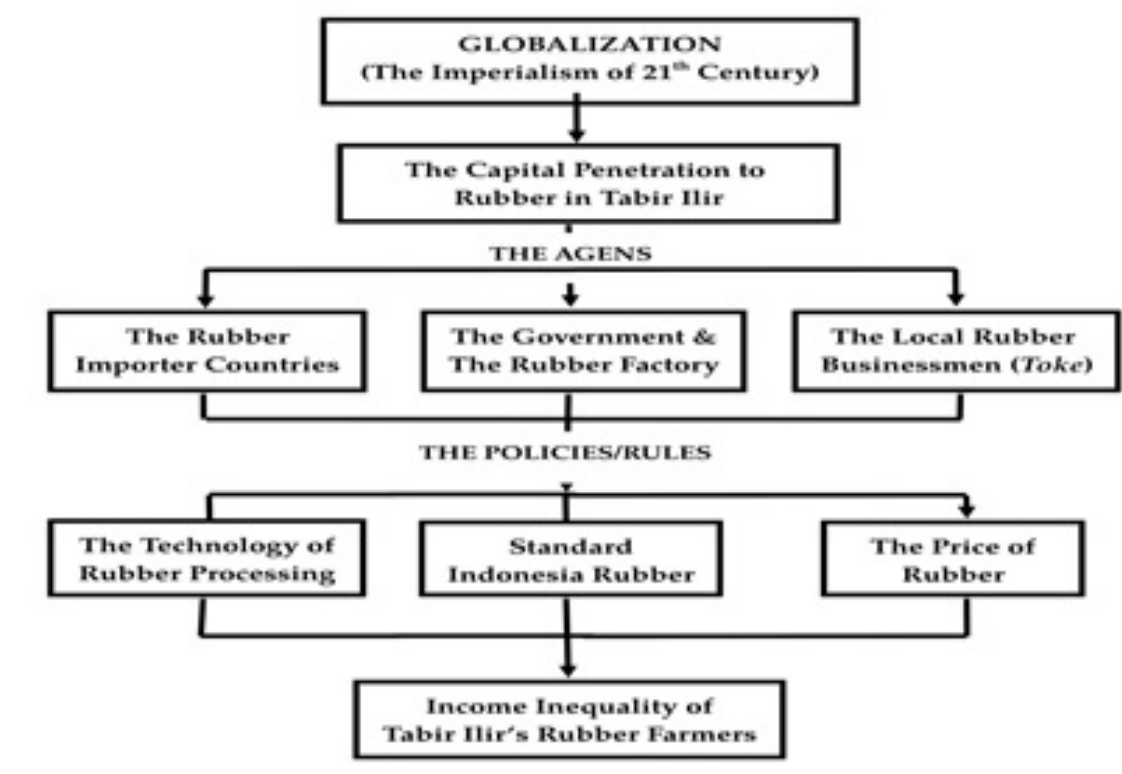

Sources: Processed data, 2016 
products become one of the main raw materials of several industries, especially transportation equipment and household. On the basis of such, some countries need rubber processing products to meet the needs of industrial raw materials that they try. Based on BPS data, USA, Japan and China are the top three countries that need the supply of Indonesian rubber to meet the needs of the industry, then followed by India, South Korea, Germany, and France (Rubber Statistics Indonesia, 2014).

According to BPS, 2,623,425 million tons (83.20\%) of Indonesia's total rubber production in 2014 (3.153.186 million tonnes) is intended for international markets or exported to the above countries (Rubber Statistics Indonesia, 2014). Based on a skeptical perspective of globalization, rubber importing countries generated from Indonesia are globalizing agents of globalization. In an attempt to control one of the main natural resources of the Third World, these importing countries do not directly do so. The penetration mission carried out by the Indonesian rubber importing countries is done in the form of determining the quality and price of the rubber market. This method of concentration is run through international commodity markets in the Singapore Commodity Exchange (Sicom) and the Tokyo Commodity Exchange (Tocom). Both of these commodity markets become the reference of quality and price of rubber at international level which then becomes a reference for rubber market price in the country through Spot Market Palembang (Peppebti, 2015). Thus it can be seen that the price of rubber is determined by the price set in the international market which is then referred to by the existing markets in the country. The high price is of course intended for quality rubber and good quality rubber products determined by the technology used to process it.

The globalization agent at the international level then cooperates with the Indonesian government and rubber factories.
The role of the Government of Indonesia is issuance of Standard Indonesia Rubber (SIR) 2000. It is the standard quality of Indonesian rubber that has been dried and refined to sheets with a predetermined size. On the one hand, the government issued SIR 2000 that must be met by rubber producers (including farmers), but on the other hand, the farmers are allowed to perform simple rubber management. As a result, rubber farmers continue to struggle with quality issues of production, productivity and price over time. Rubber products that can be produced by farmers only in the Bokar form or also known as Latex. This type of rubber product is the cheapest in the market because it still contains high water content and high levels of dirt. Quality Bokar like this is the result of technology or precisely the ability that is controlled by farmers related to the management and processing of rubber that is still simple and obtained from generation to generation.

Another role of government is the 'omnipotence' of farmers managing their simple rubber. Despite being the largest contributor to rubber concessions in Indonesia, the government seems to be turning a blind eye to the conditions experienced by farmers in trying to rubber: Bokar quality, low productivity and low prices and simple technology and marketing systems. Historically, there are actually several government policies related to efforts to overcome the problems faced by farmers, namely: Plantation Core People (PIR) and Plantation Revitalization Program at the national level and Rubber Rejuvenation Program issued by the Government of Jambi Province. Another problem faced by rubber farmers is the lack of government attention to rubber farmers in the cultivation of this plant. In reality, however, these policies have failed to address the problems faced by farmers in seeking rubber. Although the PIR has been implemented by the government, farmers still have problems with the inability to repay their 
loans, the sale of rubber materials (Bokar) out of the core, low quality of Bokar and variety and excessive rubber plantation exploitation (Padmo, 2004: 117). This is because PTP and PIR, on the one hand, monopolize technology, management, political and financial legal support from the government, while on the other hand, smallholder (and private) plantations are isolated from these facilities. Whereas the people's plantations are located in a place far from large plantations, cultivated with small capital, less extensive planting area and relatively simple technology.

The same is true with the next policy, namely the Plantation Revitalization Program that is officially valid through Regulation of the Minister of Agriculture of the Republic of Indonesia No.33/Permentan/OT.140/7/2006 and Regulation of the Minister of Finance No. RI. 117/PMK.06/2006 on Credit for Development of Plant-Based Energy and Plant Revitalization (KPEN-RP). This program is difficult to be expected as a solution to the problems faced by farmers. Implementation of this program runs slowly and this goal is difficult to achieve due to inhibiting factors that cannot be overcome (Rulyantie, 2011). The crucial problem faced in the implementation of this program is the low coordination of related parties, both government as executor and banking as a source of funding and quality of human resources is still low.

The same thing happened with Rubber Rejuvenation Policy issued by Jambi Provincial Government which also failed to solve the problems faced by rubber farmers, namely quality, and price. This program also did not touch the farmer of Tabir Ilir rubber in its implementation.

Another indication of 'omission' by the government is not to make an effective effort to overcome the main problem faced by rubber farmers, namely price issues. The low selling price of rubber products that resulted in the farmers getting a small and minimal advantage of its activities to manage this commodity. In an effort to overcome this problem, the government only formed Badan Pengawas Perdagangan Berjangka Komoditi (Bappebti)/ Commodity Futures Trading Supervisory Agency under the Ministry of Trade of the Republic of Indonesia. As the name implies, Bappebti only serves as a traffic controller of various commodities, one of them rubber, without any authority to determine the price. The amount of price applied to one commodity, one of which is rubber, remains the domain of the international market, or in other words, the price of a commodity is left entirely to the global market mechanism.

In this context, the amount of rubber price that should be used by all parties working on it is based on market decisions in Singapore Commodity Exchange (Sicom) and Tokyo Commodity Exchange (Tocom). The two institutions that serve as the benchmark for world trade, mainly in Asia, are the manifestations of global capitalism through the hands of the Forward Countries with a great interest in rubber. Bappebti publishes commodity price information traded to trade services as well as plantation and forestry services throughout Indonesia, including to the Merangin Regency Plantation and Forestry Office.

Another role that the government, especially the local government, is not providing facilities and infrastructure that are conducive to supporting the management of rubber in Tabir Ilir. As it is known that the rubber gardens cultivated by the farmers of Tabir Ilir are far from their settlements, even some of them are located outside the Merangin Regency, in Bungo, Tebo and Sarolangun Regencies. Rubber products produced by Tabir Ilir farmers which will be sold to Toke and must travel a long distance on poor road conditions. Roads used for transportation activities of these farmers' rubber products are mostly in poor condition, especially in the rainy season, although some 
of the sections are already paved. Actually, the local government is not paying any attention to the condition of this road, but the quality of the asphalt does not match with its designation.

As the main road used to transport rubber, the asphalt condition of the road is below standard because it is so thin that it is easily damaged and resulted in the emergence of gaping holes. The condition of this road makes rubber car transporters difficult to operate and takes longer time. When it comes to the rainy season, the streets become full of water and mud, while in the dry season, the main road to the rubber plantation is the main source of air pollution due to the flying dust.

Another globalization actor at the national level is a corporation that owns a rubber processing factory that houses or buys the rubber produced by the farmers of Tabir Ilir. It is this rubber processing factory that buys and collects the rubber produced from farmers known as Latex to be processed into rubber crumb type SIR 10, SIR 20 and SIR 20VK. The types of rubber products produced by the factories are in accordance with the established standard (SIR), i.e.,e the dirt content of no more than $0.10 \%$ (SIR 10) and $0.20 \%$ (SIR 20) and so forth according to the provisions set forth in SIR 2000 and the provisions of international rubber trade held by processing plants (Napitupulu, 2011). After the rubber is processed according to the specified specifications, then the processing company sells it to meet the demand of the industry, especially tires, both national and international scale. Thus, it can be said that only the factory can process the rubber into a product that can meet the required specifications, both in accordance with the SIR and the standards traded on the international market.

These factories only process rubber production of semi-finished farmers, which produce and market the crumb rubber type SIR 10, SIR 20 and SIR 20VK, to meet the demand of the national and international tire industry. Rubber-processed rubber factories with various variants of this is a product that is highly qualified and needed by industries that use rubber raw materials, such as tires and hoses. The quality of this product is produced because the factory has a variety of equipment and processing machines are much better and modern. In addition to catering to domestic needs, manufactured rubber products are mostly intended for export to various countries: USA, Japan, China, India, South Korea, Germany, and France (Rubber Statistics Indonesia, 2014).

Like previous globalization agencies at the national level, there is a similar indication of 'omission' by the processing plant to the simple rubber farmers' processing techniques. This assumption arises because it turns out the processing factory is still buying rubber products produced by farmers, even at the lowest level of quality though, of course with a very low price too. This is done because the processing plant has a special tool that can sort the dirt in the rubber products of the farmers so that it becomes a product with higher selling value. Thus, it can be said that the simple processing techniques of rubber farmers become the profit for the factory, or in a more critical expression that the condition is actually a profit for the factory, so it is worth to continue to be preserved.

Based on data, there are some rubber processing factories operating in Jambi Province and using rubber materials of Jambi, namely: PT Batanghari Tembesi, PT Jambi Waras I, PT Angkasa Raya, PT Hongtong, PT Remco, PTP Nusantara VI, PT Aneka Bumi Pratama, PT Jambi Waras II, PT Dasa Anugerah Sejati, PT Djambi Waras-Jujuhan, PT Anugerah Bungo Lestari, PT Lembah Karet (West Sumatra), PT Kirana Sapta (North Sumatra), PT Pantja Surya (North Sumatra), and PT Kirana Windu (South Sumatra).

The local agen of globalization is local entrepreneurs (toke) becomes a very significant party because it interact directly with the object 
being mastered (rubber) as well as meeting with the main producers (farmers). Positions like this make toke also share the sweet, bitter and bitter experience experienced by farmers in rubber cultivation, so it becomes a product that is needed many people. Based on data, there are ten toke that act as 'globalization agent' at the local level in rubber management in Tabir Ilir. These ten local entrepreneurs are buying and collecting rubber produced by farmers in Tabir Ilir, in accordance with the management agreement they apply.

Although it consists of ten local entrepreneurs, actually entrepreneurs who really affiliated directly with the rubber processing plant consisting of only two Toke, namely: A Sung and $\mathrm{H}$. Yusuf. These two local rubber entrepreneurs have direct access to rubber processing factories, because they have sufficient farmers' equipment and processing equipment. Other local entrepreneurs do not deal directly with rubber processing factories, but their interactions are made through the two Toke intermediaries above. These ten local entrepreneurs are directly related to the farmers by buying and accommodating the rubber of their products. Because different in the relationship pattern with the rubber processing plant, the profit earned each Toke in Tabir Ilir is also not the same. As a local entrepreneur directly related to the rubber plant, the A Sung and $\mathrm{H}$. Yusuf families certainly benefit more from the sale of rubber to the processing plant than the other Toke associated with the factory through these toke. As an illustration, if the rubber sold A Sung and $H$. Yusuf Family valued IDR. 10,000 per kilogram, the other rubber Toke will be bought by both Toke at the highest IDR. 7,000 per kilogram. The magnitude of this price is then used as a reference by other toke to buy rubbers produced by Ilir Tabir farmers. Therefore, the quality of rubber products produced by farmers, in general, is below the standard as a reference, the farmers will get a price far below the prevailing prices in the market.

Based on the data, Toke will divide the rubber products produced by farmers into two categories: 'dry rubber' produced by farmers several weeks before weighing time ( 1 to 2 months) and 'wet rubber' produced several days before weighing time. With better quality and relatively low water content under SIR conditions, 'dry rubber' will be priced at IDR. 4,000 per kilogram. Meanwhile, with lower quality due to the high water content based on the SIR quality standard, 'wet rubber' will be priced at the highest IDR. 2,500 per kilogram. The amount of price applied by Toke to rubber products produced by farmers is based on the assumption of rubber market price of IDR. 9,000 per kilogram.

Such is the mechanism that prevails in the management and trade of rubber in Tabir Ilir applied by Toke. In general, the farmers of Tabir Ilir rubber produce more rubber products that are categorized as wet (moisture content in excess of SIR provisions), so the income earned

Table 3.

Revenue Comparison of Rubber Management Perpetrators in Tabir Ilir

\begin{tabular}{clcc}
\hline \multirow{2}{*}{ No } & \multicolumn{1}{|}{ Category of Rubber Revenue Manager } & \multicolumn{2}{c}{ Income (millions) } \\
\cline { 3 - 4 } & & Per 2 months & Per Year \\
\hline 1 & Owner (Toke) with biggest rubber area (5.000 Ha.) & $>$ IDR 200 & $>$ IDR 1.2 Billions \\
2 & Owner (Toke) with smallest rubber area (100 Ha.) & $<$ IDR 6 & $>$ IDR 120 \\
3 & Small Owner with biggest rubber area (20 Ha.) & $<$ IDR 4 & $<$ IDR 24 \\
4 & Small Owner with smallest rubber area (10 Ha.) & $<$ IDR 4 & $<$ IDR 24 \\
5 & Rubber tapper (Javanese) & $<$ IDR 2 & $<$ IDR 12 \\
6 & Rubber tapper (Local) &
\end{tabular}

Source: Data processed from research results, 2016. 
is not too large. Conversely, Toke who collect and buy rubber produced by farmers will dry the wet rubber before it is sold to the factory. In fact, some Toke process first rubbers produced farmers into sheets in accordance with the provisions of the plant using special equipment so that the selling price becomes higher.

\section{The Offer of Innovative Policies on Rubber Farmer}

Based on the views of the skeptics above, it can be concluded that the role of the state in development must be still existing and strengthened. Related to the discourse of the significant role of the state in overcoming these public problems, the New Public Service (NPM) paradigm is worth putting forward. The concept promoted by Janet V. Dernhart and Robert B. Dernhart (2003) is a criticism of the Reinventing Government proposed by David Osborne and Ted Gaebler. As a criticism of another form of New Public Management (NPM) which is the mainstream paradigm in the role discourse of the State, NPS assumes that running a government administration is not the same as managing a business organization; because it must be mobilized as it moves democratic government. The mission of a public organization is not just to satisfy the service user, but also to provide goods and services as the fulfillment of public rights and obligations.

Based on the NPS concept, the government through its bureaucratic system along with other stakeholders should be able to innovate to create breakthrough solutions to problems faced by rubber farmers. This is because previously the government only acted as a regulator that only came to produce SIR and three policies (PIR, Plantation Revitalization, and Rubber Garden Rejuvenation) which proved to be not solutive. Orientation to meet domestic needs is a vision that must be focused by the government so that rubber products produced by farmers are not always dependent on exports. With the vision of the fulfillment of the domestic market, the government can play a more significant role in providing solutions for rubber farmers to address the problems they face.

This effort as prominent with the plan of utilization of rubber products as a mixture of asphalt, as already done in Thailand and Malaysia (http://ekbis.sindonews.com/read, access dated February 1, 2016). Based on research conducted by Amal (2011), mixing rubber (Latex) with asphalt will make the asphalt becomes thicker and denser because air cavity will be smaller, so it becomes stronger and durable. In addition, the addition of Latex on asphalt can also reduce the amount of asphalt used in the mix for highway pavement to save the use of natural resources. In addition, the use of rubber in asphalt will save road maintenance costs by up to $40 \%$, although on the other hand the cost of production increases to $20 \%$ (http://industri.bisnis.com, access July 28 , 2016). Mixing natural rubber, the quality of asphalt can be better because the level of elasticity is higher, so the road is not easily damaged (http://economy.okezone.com, access July 28, 2016).

Based on the experience of Malaysia and Thailand that have long adopted this method, the use of rubber as a mixture of asphalt is financially more expensive, but on the other hand, will increase domestic rubber use up to $40 \%$ to $50 \%$. Still, in the same context, Malaysia is more advanced by utilizing rubber not only for asphalt raw materials, but also used for Mass Rapid Transit (MRT) bearings. Based on the experience of Malaysia and Thailand, then by focusing the use of rubber for domestic needs will increase the number of rubber products Indonesia. If in 2014, Indonesia's total rubber production amounted to 3,153,186 tons, there will be 1,261,274.4 tons consumed domestically, assuming a $40 \%$ increase after only 529,761 tons (18.8\%).

Another innovative policy that can be done in an effort to increase domestic rubber 
consumption is to encourage the national tire industry to expand to nearby rubber plantation and production centers (http://ekbis. sindonews.com/read, access dated February 1 , 2016). As it is known that as much as $55 \%$ of rubber products consumed in Indonesia (291,368.6 tons) are utilized by the tire industry to be used as the main raw material. In an effort to obtain industrial raw materials, national tire manufacturing plants work with rubber processing factories (BPS, 2014). With the establishment of tire manufacturing plants near rubber centers, the effort to obtain raw materials can be made directly (shorter) without going through other intermediaries as it has been done.

Based on the policies mentioned above, the government is expected to no longer repeat agricultural politics ever undertaken by the Dutch government first. Initially, the Dutch did facilitate the people to grow rubber in their land area through the provision of rubber seeds in the demonstration gardens (Lindayanty, 2013: 87). However, after the people's rubber developed quite rapidly, the Dutch implemented a variety of policies that would not benefit farmers. This effort is a Dutch strategy to double the economic and political benefits of rubber exploitation.

The Dutch policies relating to rubber are shaded by the Agrarian Law 1870 which gives the private sector the widest possible space to invest in Indonesia (Padmo, 2004: 111). Through this regulation, the private sector obtains land tenure concessions in the long term, establishes a plantation bank and legal and political protection. The form of implementation of this regulation is the emergence of cheap labor wage policy, the provision of facilities and infrastructure for the interests of private companies, and suppress the production of smallholder rubber to maintain the existence of private companies (Padmo, 2004: 112113). As a ruler, the Dutch government in the past was very unconcerned with the fate experienced by farmers and how they survived, because farmers were only seen as a means of producing something with as much as possible to provide benefits and benefits to the authorities. This was as prominent as the Dutch policy of raising taxes on rubber for farmers' production, from 10 cents per kilogram in 1934 to 59 cents per kilogram in 1936 (LocherScholten, 2002: 173). In addition, the Dutch also implements agricultural politics that make the government not directly in touch with farmers, but the relation is made through intermediaries (comprador) consisting of Chinese (Padmo, 2004: 112). Consequently, the policies adopted by the Dutch government did not favor the peasants for not touching the real problems they experienced, but only on the needs of these intermediaries.

Efforts to meet the needs of this country in line with the Deglobalization concept. According to Bello (2004), Deglobalization is an attempt to re-orient the domestic economy from the emphasis on production for export to production needs for local markets. This thinking is Bello's response to the phenomenon of continuing food problems in this era of globalization. On the one hand, the neo-liberal system of the last two decades has been able to push globalization toward competition that shows quite favorable levels of economic progress and productivity, but on the other hand, there are problems, increasing the level of competition and reducing the profits of companies and business actors.

Theemergence of Deglobalization is not an attempt to oppose the economic linkage between one country and another, as globalization agencies have always expressed and no attempt to withdraw from the international community. Deglobalization, however, places more emphasis on making the fulfillment of the domestic market's needs a primary concern. Deglobalization is an effort to make new production, exchange, and distribution in a new world order involving only community- 
owned cooperatives, local private companies, and state-owned enterprises. In a world like that, the wheels of the economy do not involve transnational corporations at all. Thus, Bello's (2004) paradigm holds a fundamental characteristic of demands for the production of goods and services that respond to the needs of society, not a demand created by a consumer culture driven by corporations, capital, and markets. This perspective of Deglobalization has become one of the strategic approaches to counteracting globalization which is claimed to be a new imperialism with a set of actors. For supporters of Deglobalization, the state is a very important fortress to stem global corporate power by not opposing the links between different countries and international exchanges.

In addition to efforts to meet domestic rubber needs, the government is also expected to educate farmers to apply the principles of rubber management more advanced. This can be done by providing training on rubber processing skills according to SIR and equipment assistance needed for the products produced by farmers selling high in the market. This effort is needed because the farmers who are the main producers of rubber needs so far have never received any skills training, as happened in Tabir Ilir. This solution is a response to the low quality of rubber production produced by farmers so far because they still apply simple management methods.

Based on the government policy that implements this New Public Service and Deglobalization concept, the income inequality that has always been attached to farmers will be reduced. Reduced levels of income inequality will occur because the chain of utilization of rubber products will be cut. The parties involved in the marketing of rubber produced by farmers are no longer as numerous as reaching countries in other parts of the world (such as the United States), now the utilization of the end is shorter because it is within the country itself (government and businesses made from rubber raw materials). Advantages that have been enjoyed by many other parties because of the length of the chain of rubber utilization will be able to move to the farmers so that it has implications for improving the welfare of their lives.

In addition, the orientation of domestic rubber needs fulfilled by the government can also overcome the price problem which has been a problem faced by farmers because it is no longer dependent on importing countries. Because the government itself is using rubber for various domestic purposes, the government can fix the price of rubber products produced by farmers without dependent on foreign countries. It is known that as much as $83.20 \%$ $(2,623,425$ million tons) of Indonesia's rubber products in 2014 is aimed at exports to various countries, namely: the United States, Japan, China, South Korea, India, Germany, and France (Rubber Statistics Indonesia, 2014). Thus, the prices imposed on rubber are strongly influenced by the terms set by importing countries which are practiced in practice by the Singapore Commodity Exchange (Sicom) and Tokyo Commodity Exchange (Tokom). With the orientation of the fulfillment of the domestic market to supply the needs of road construction projects (for asphalt mixtures) and various other projects, the government can control its own price because the government itself uses it.

In addition, the provision of good infrastructure for rubber management also needs serious attention by the local government. As it is known that one of the obstacles faced by farmers in managing the rubber they have is infrastructure, especially roads, are not adequate. This unfavorable road condition, in addition to impeding the mobility of transporting produce as it takes longer time, also has implications for the swelling of expenditure items for fuel. As a result, in 
addition to the profits from the sales of rubber products to be shared equally with other management actors, rubber farmers also have to spend more on transportation. Conversely, if the roads used by farmers are in good condition, then some funds for transportation can be diverted to other aspects they need to improve their standard of living.

\section{Conclusion}

As the main stakeholder of rubber management $(85.10 \%)$, farmers should live in welfare because the efforts they generate produce 4,741,489 million U\$D. But in reality peasant life remains in a state of limitations because the results they get are not as expected. This condition occurs because the management of rubber by farmers still leaves some problems, namely: low product quality, low productivity, as well as technology and a simple marketing system. As a result, the selling price of rubber production of farmers is very far from the prevailing prices in the market so that it has implications on the income it earns.

Based on the perspective of globalization skeptics, it is necessary to have a significant government role in overcoming the problems faced by rubber farmers above. In this context, the government through its bureaucratic system has a role in producing a series of innovative-solutive development policies and programs in order to prevent people from the negative impacts of globalization. This effort can be run by the government by adopting NPS paradigm as part of a good public service effort for the people as citizens guaranteed by the Constitution. Implementation is done following the concept of Deglobalization by prioritizing the fulfillment of domestic needs as the main interest. In this context, the need for a policy of transfer of rubber orientation from what has been destined for export purposes $(84.10 \%)$ is in the domestic interest. Large domestic rubber production can be used for the purpose of raw materials for road construction by mixing asphalt with rubber that proved successful in Malaysia and Thailand. Financially it is expensive, but on the other hand, it will increase domestic rubber usage from $40 \%$ to $50 \%$. If in 2014 , Indonesia's total rubber production amounted to 3,153,186 tons, there will be 1,261,274.4 tons consumed domestically, assuming a $40 \%$ increase after only 529,761 tons (18.8\%).

Another policy is to bring rubber industry closer to rubber centers as well as to educate farmers to improve the quality of their products and improve road facilities and infrastructure. Given these policies, the dependence on exports that have implications on rubber prices can be overcome because the domestic people themselves, especially the government, who use rubber for various purposes.

\section{References}

Amal, A. S. (2011). Pemanfaatan getah karet pada aspal Ac 60/70 terhadap stabilitas Marshall pada Asphalt Treated Base (ATB). Media Teknik Sipil, 9(1), 8-16.

Amin, S. (2001). Imperialism and globalization. Journal Monthly Review, 5(11), 157-168.

Badan Pusat Statistik (2014). Indonesia dalam angka. Jakarta: BPS.

Badan Pusat Statistik. (2014). Statistik karet Indonesia. Jakarta: BPS.

Bappebti. (2015). Daftar harga komoditas di Indonesia. Jakarta: Kementerian Perdagangan RI.

Bello, W. (2004). Deglobalization: Ideas for a new world economy. New York: Zed Books.

Bryan, L. \& Farrell, D. (1996). Market unbound: Unleasing global capitalism. New York: John Wiley.

Chakrabarty, D. (2000). Provincializing Europe. London: Routledge.

Denzin, N. K. \& Lincoln, Y. S. (2009). Introduction: entering the field of qualitative research. In N. K. Denzin \& Y. S. Lincoln. (Eds.). Handbook of Qualitative Research. 
Thousand Oaks, CA: SAGE.

Dernhart, J. V. \& Dernhart, R. B. (2003). The New Public Service: Serving, Not Steering. New York: M.E Sharpe.

Fajriah, L., R. (2016). Penggunaan karet lewat instruksi Presiden. Retrieved from http:// ekbis.sindonews.com/read/1066625/34/ kemendag-dorong-penggunaan-karetlewat-instruksi-presiden-1449150438.

Friedman, T. (2007). The world is flat: A briefhistory of the twenty-first century. New York: Picador. Giddens, A. (1990). The consequences of modernity. California: Stanford University Press.

Giddens, A. (2002). Runaway world: How globalization is re-shaping our lives. London: Profile Books.

Glienmourinsie, D. (2016). Menperin Dorong Industri Ban Ekspansi ke Hulu. Retrieved from http://ekbis.sindonews. com/read/1056636/34/menperin-dorongindustri-ban-ekspansi-ke-hulu-1445942850.

HM, Pahrudin. (2014). Relasi patronase dalam perkebunan karet rakyat. Jurnal Sosiologi "Reflektif", 8(2), 195-215.

Jati, W. R. (2012). Ketimpangan utara-selatan dalam globalisasi. Jurnal Studi Hubungan Internasional, 2(2), 83-101.

Jati, W. R. (2013). Memahami globalisasi sebagai evolusi kapitalisme. Jurnal Global dan Strategis, 7(2), 241-258.

Lindayanty. (2013). Jambi dalam sejarah 15001942. Jambi: Dinas Kebudayaan dan Pariwisata Provinsi Jambi.

Loadman, J. (2005). Tears of the tree: the story of rubber-a modern marvel. New York: Oxford University Press.

Locher-Scholten, E. B. (2002). Berdirinya kekuasaan kolonial di Jambi: partai ganda politik \& ekonomi. Fondasi Historis Ekonomi Indonesia. In J. Thomas Lindblad (Ed.). Yogyakarta: Pusat Studi Sosial Asia Tenggara UGM-Pustaka Pelajar.

Marvasti, A. B. (2004). Qualitative Research in Sociology. London: SAGE Publications.

Mitrović, L. (2010). The new bourgeoisie and its pseudo-elite in the societies of peripheral capitalism (a sketch for a sociological portrait). Facta Universitatis Series: Philosophy, Sociology, Psychology and History, 9(1), 1-13.

Murshed, S., M. (2002). Globalization, marginalization, and development. London: Routledge.

Napitupulu, D. (2011). Kajian tata niaga karet alam: Upaya peningkatan kesejahteraan petani. Jurnal Penelitian Karet, 29(1), 79-92.

Padmo, S. (2004). Perusahaan tanaman karet di Sumatera Timur, bunga rampai sejarah sosial-ekonomi Indonesia. Yogyakarta: Aditya Media-Fakultas Ilmu Budaya Universitas Gadjah Mada.

Petras, J. \& Veltmeyer, H. (2001). Globalization unmasked: Imperialism in $21^{\text {st }}$ century. London: Fernwood Publishing and Zed Books.

Pratiwi, D., A. (2016, July 28). Aspal dicampur karet kualitasnya lebih tahan lama. Retrieved from http://economy.okezone. com/read/2015/04/09/320/1131761/aspaldicampur-karet-kualitasnya-lebih-tahanlama.

Ritzer, G. (2006). The globalization of nothing: Mengkonsumsi kehampaan di era globalisasi. Yogyakarta: Universitas Atma Jaya.

Rulyantie, S. (2011). Studi implementasi kebijakan program revitalisasi perkebunan di Provinsi Kepulauan Bangka Belitung. (Unpublished master's thesis). Magister Administrasi Publik Universitas Terbuka.

Shiva, V. (2004). Peraturan pertanian WTO: ancaman bagi para petani dunia ketiga. Globalisasi, kemiskinan dan ketimpangan. International Forum on Globalization (IFG). Yogyakarta: Cindelaras Pustaka Rakyat Cerdas.

Steger, M. B. (2002). Globalism: The market ideology. Boston: Rowman and Littlefield.

Sunarti. (2011). Tingkat Kesesuaian Lahan di DAS Batang Bungo Untuk Tanaman Karet. Jurnal Hidrolitan, 2(2), 16-25.

Winarno, Budi (2005). Globalisasi wujud imperialisme baru: peran negara dalam 
pembangunan. Yogyakarta: Tajidu Press.

Wolf, M. (2005). Why globalization works. New Haven: Yale Notabene.

Wolf, M. (2016). Will the nation-state survive globalization? Retrieved from https://www. foreignaffairs.com/articles/2001-01-01.

Wulandari,D.(2016).Aspalkaret:tahundepanmulai diterapkan. Retrieved from http://industri. bisnis.com/read/20160412/45/537204/aspalkaret-tahun-depan-mulai-diterapkan 